\title{
OBSERVATIONS ON THE EFFECT OF „FERTOSAN“— AND „QR“- PREPARATIONS UPON THE HUMIFICATION OF STRAW.
}

\author{
BY \\ Armi Kaila And Anja-Meri Pohjanpä̈̈ \\ University of Helsinki, Department of Agricultural Chemistry \\ Received 18th March 1952 .
}

The utilization of surplus straw has formed an actual problem in Finland during the last years. In addition to the ploughing in of straw with nitrogen fertilizers or the use of straw as litter in larger quantities, fermenting of straw in composts has been recommended. The latter method contains, however, several technical weak points, the most important of which seems to be the insufficient moistening of raw straw that leads to an unequal, slow and incomplete humification of the material.

Recently two humifying preparations have been obtainable even in Finland: the bacterial preparation "Fertosan" and the possibly biodynamic preparation "QR". According to the advertisements, both of them are able to accelerate the decomposition of organic material in such a degree that even straw turns into good humus within six weeks. It is stated that this occurs without any application of nitrogen or other minesal nutrients, and that it is due only to the very effective bacteria in "Fertosan" or the substances in "QR" which are claimed to activate the microbial processes to an enormous degree.

In order to investigate the value of these preparations some experiments were performed both under laboratory conditions and on a larger scale. The effect of these preparations upon humification of rye straw was compared with that of an usual application of nitrogen and phosphorus fertilizers.

\section{Arrangement of the experiments.}

The incubation experiments under laboratory conditions included three series:

1. Straw with farm manure

2. Straw with lime $\left(\mathrm{CaCO}_{3}\right)$ 
3. Straw with nitrogen and phosphorus applications

In the first two experiments the composts treated with "Fertosan" or "QR" were compared with untreated ones and with those which received an application of urea and potassium monophosphate. The object of the third series was to show, if the preparations would accelerate the decomposition under favourable conditions, i.e. when nitrogen and phosphorus fertilizers were applied to satisfy the needs of a large microbial population.

In all these experiments chopped rye straw was used. 300 grams of air-dry straw was packed into 3 liter glass jars, and moistened with $900 \mathrm{ml}$ of tap water into which the fertilizers or the "Fertosan" or "QR" suspensions were dissolved. This amount of water ensures aerobic conditions for the decomposition $(5)$. In the series with farm manure $250 \mathrm{~g}$ of fresh manure was mixed with dry straw before packing. In the lime series $50 \mathrm{~g}$ of calcium carbonate was mixed with straw. This series received $20 \mathrm{ml}$ of extra water to moisten the lime added. The "Fertosan" and "QR" suspensions were prepared according to the instructions in the prospectus. Nitrogen was applied as urea and phosphorus as potassium monophosphate, the amount of nitrogen being 0.7 per cent of the air-dry straw, and that of phosphorus 0.1 per cent. These amounts were calculated to be sufficient for a rapid decomposition of straw $(4,2)$. All the treatments were in duplicates.

The pots were loosely covered with plastic in order to prevent the evaporation of water. The temperature of the incubation room was kept at $25-27^{\circ} \mathrm{C}$ for the first three weeks in order that the decomposition could get a good start. Later on, the temperature varied between $17^{\circ}$ and $22^{\circ} \mathrm{C}$.

The compost experiments on a larger scale were arranged in two series:

1. Straw with farm manure

2. Straw with lime

The treatments that were compared in the series with farm manure were "Fertosan", "QR" and mineral nutrients nitrogen and phosphorus. The treatments in the series with lime differed from those of the first series in the "QR»-compost which received an application of nitrogen and phosphorus. All the treatments were in duplicates.

Long rye straw from the preceding summer was used in these experiments. It was moistened well before it was deposited in layers with manure or lime, and each layer of straw was treated with Fertosan or $" Q R$, suspensions or with fertilizers. The preparations and urea were applied in water that was used for the moistening of each layer, superphosphate was strewed dry. The composts were $1.2 \mathrm{~m}$ high and their area $2 \times 1.5 \mathrm{sq} \mathrm{m}$. The amounts of manure, lime and mineral fertilizers were calculated to correspond

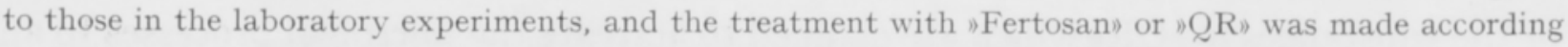
to the instructions in the prospectus.

These experiments were started in the middle of May 1951. In order to keep the composts moist enough they were watered every week or every two weeks during the first months.

\section{The methods used for the analyses.}

As humification experiments are in question, it is not easy to choose analytical methods that distinctly indicate the inferiority or the superiority of the products received under various conditions. In experiments like those reported in this article, the velocity of decomposition seems to be of importance, and therefore the loss of dry matter may give some information wanted. However, the quality and the quantity of the humus formed during decomposition cannot be excluded when the value 
of any humification method is to be estimated. Unfortunately, we have no rapid and useful analytical procedure for this purpose. The samples taken in these experiments were analysed using a rapid fractionation that was modified from the ordinary Waksman-procedure (6) and from the method used by Millar et al. (3).

Five grams of the ground air-dry sample was extracted for three hours with a mixture of ethanol and benzene (1:1). Then the residue was treated for five hours with $150 \mathrm{ml}$ of N/2 hydrochloric acid in boiling water-bath, filtrated and dried. Two one gram portions of this residue were then moistened with $10 \mathrm{ml}$ of $80 \%$ sulfuric acid and after standing for $2 \frac{1}{2}$ hours diluted with $150 \mathrm{ml}$ of distilled water and autoclaved for one hour at $120^{\circ} \mathrm{C}$. The amount of organic matter in the residues was determined. The decrease in organic matter in each extractions was calculated from the amounts of dry matter and of ash before and after the treatments.

It is not attempted to estimate any distinct compounds by this fractionation method. However, according to the results of some other experiments it seems, from the point of view of the humification process, to give a fairly clear picture of the composition of the organic material in question. The easily soluble and hydrolyzable organic matter in the $\mathrm{HCl}$-extract is not of importance as an indicator of the state of humification, since it seems to vary irregularly. The organic matter that is dissolved by the treatment with sulfuric acid is mostly cellulose, and the decrease in it seems to be correlated with the advancement of humification. The insoluble organic matter contains lignins and its derivatives, real humine substances and nitrogen compounds. It increases relatively but not absolutely during the decomposition, and it gives some information of the state of humification. However, one must not forget that this fraction contains also other compounds than real humus substances, and that the quality of the humus is even more important than its quantity.

Other chemical analyses performed from the samples of these humification experiments included the determination of total nitrogen by the common Kjeldahlprocedure and the estimation of the soluble nitrogen fractions from extracts of $2 \mathrm{~N} \mathrm{KCl}$. The $\mathrm{pH}$-values were measured directly from the moist material with a Radiometer using the glass electrode. The microbial investigations included only macroscopic observations and the examination of CHoLodny-plates (1) at various intervals.

\section{Results.}

After a humification period of three weeks the straw mass in the laboratory experiments was only slightly changed in the pots without fertilizers but even in the farm manure series the fertilizers had markedly increased the darkening and softening of straw.

The effect of nitrogen and phosphorus applications was visible even in the macroscopic population of the straw mass. In pots without mineral fertilizers some light brown molds dominated, while the more luxurious conditions in pots with fertilizers gave rise to a white mold flora. Representatives of Basidiomycetes were found in abundance in all the pots containing farm manure but they were not completely lacking in the other pots that contained fertilizers. 
The Cholodny-plates which were examined after the incubation for six weeks did not show any special flora in the composts treated with "Fertosan" or "QR". Bacteria, molds and actinomycetes seemed to be similar to those in the corresponding pots without the preparations.

Since the pots were not very large, no differences between the temperatures of the various straw masses could be found. Their temperature was during the first weeks approximately only one degree higher than that of the laboratory.

No distinct differences existed in the $\mathrm{pH}$-values of the straw mass, neither in the beginning nor in the end of the experiments, as can be seen from the following data:

\begin{tabular}{|c|c|c|}
\hline Treatment & $\mathrm{pH}$ after 3 weeks & $\mathrm{pH}$ after 6 months \\
\hline 1. Straw and farm manure & & \\
\hline $0 \ldots \ldots \ldots \ldots \ldots \ldots \ldots \ldots \ldots \ldots \ldots \ldots$ & 8.3 & 7.3 \\
\hline Fertosan $\ldots \ldots \ldots \ldots \ldots \ldots$ & 8.4 & 7.4 \\
\hline${ } \mathrm{QR}, \quad \ldots \ldots \ldots \ldots \ldots \ldots \ldots \ldots$ & 8.4 & 7.8 \\
\hline $\mathrm{N}$ and $\mathrm{P} \quad \ldots \ldots \ldots \ldots \ldots$ & 8.1 & 7.9 \\
\hline 2. Straw and lime & & \\
\hline 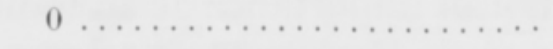 & 8.6 & 8.6 \\
\hline Fertosan $\ldots \ldots \ldots \ldots \ldots \ldots$ & 8.6 & 8.3 \\
\hline$" Q R " \ldots \ldots \ldots \ldots \ldots \ldots \ldots$ & 8.6 & 8.3 \\
\hline $\mathrm{N}$ and $\mathrm{P} \quad \ldots \ldots \ldots \ldots \ldots$ & 8.3 & 8.5 \\
\hline 3. Straw & & \\
\hline $0 \ldots \ldots \ldots \ldots \ldots \ldots \ldots \ldots \ldots \ldots$ & 8.5 & 7.5 \\
\hline $\mathrm{N}$ and $\mathrm{P} \quad \ldots \ldots \ldots \ldots \ldots$ & 8.4 & 7.4 \\
\hline $\mathrm{N}, \mathrm{P}$ and ${ }^{\prime}$ Fertosan $" \quad \ldots \ldots$ & 8.4 & 7.4 \\
\hline $\mathrm{N}, \mathrm{P}$ and ${ }^{\mathrm{Q}} \mathrm{QR}, \ldots \ldots \ldots \ldots$ & 8.4 & 7.7 \\
\hline
\end{tabular}

The samples for the chemical analyses were taken from the pot experiments after the incubation periods of six weeks and of four months. The results received by the fractionations are in Table 1. Since no significant differences occurred between the values for various nitrogen fractions, these data are not reported.

A treatment with "Fertosan» or "QR" had no effect on the velocity of the decomposition, since the losses of dry matter in the "Fertosan» -or "QR»-pots were not higher than in the corresponding pots without the preparations. Nitrogen and phosphorus, on the contrary, have increased the loss of dry matter to circa twice as high as in all the pots without fertilizers. The decomposition was especially slow in the straw-lime series, if no nitrogen and phosphorus were applied.

The data for the total nitrogen content of the humifying matter show an equality between the pots with the same application of mineral fertilizers in spite of the treatment with "Fertosan" or "QR». A similar effect is found to occur even in the most important fractions, in the amounts of the sulfuric acid soluble and the insoluble organic matter, as well as in the ash content. The tact must be taken into consideration that only the data within each series are comparable, since the farm manure and the lime cause some changes in the percentage composition of the material.

In Table 1 the data are reported on the basis of the humified dry matter. The differences between the effects of the various treatments upon humification appear even more markedly from the values of sulfuric acid soluble organic matter expressed 
Table 1. Composition of the humifying matter in the incubation experiments under laboratory conditions (Expressed as a percentage of dry matter.)

\begin{tabular}{|c|c|c|c|c|c|c|c|c|c|c|c|c|}
\hline \multirow{4}{*}{ Treatment } & \multicolumn{6}{|c|}{ After 6 weeks } & \multicolumn{6}{|c|}{ After 4 months } \\
\hline & \multirow{3}{*}{$\begin{array}{c}\text { Loss } \\
\text { of dry } \\
\text { matter }\end{array}$} & \multirow{3}{*}{$\begin{array}{c}\text { Tot. } \\
\text { N }\end{array}$} & \multicolumn{3}{|c|}{ Organic matter } & \multirow{3}{*}{ Ash } & \multirow{3}{*}{$\begin{array}{c}\text { Loss } \\
\text { of dry } \\
\text { matter }\end{array}$} & \multirow{3}{*}{$\begin{array}{l}\text { Tot. } \\
\text { N }\end{array}$} & \multicolumn{3}{|c|}{ Organic matter } & \multirow{3}{*}{ Ash } \\
\hline & & & \multicolumn{2}{|c|}{ soluble in } & \multirow{2}{*}{$\begin{array}{c}\text { in- } \\
\text { soluble }\end{array}$} & & & & \multicolumn{2}{|c|}{ soluble in } & \multirow{2}{*}{$\begin{array}{c}\text { in- } \\
\text { soluble }\end{array}$} & \\
\hline & & & $\mathrm{HCl}$ & $\mathrm{H}_{2} \mathrm{SO}_{4}$ & & & & & $\mathrm{HCl}$ & $\mathrm{H}_{2} \mathrm{SO}_{4}$ & & \\
\hline 1. Straw and manure & & & & & & & & & & & & \\
\hline $0 \ldots \ldots \ldots \ldots \ldots$ & 9 & 1.0 & 27 & 29 & 23 & 11 & 44 & 1.2 & 28 & 23 & 28 & 13 \\
\hline$"$ Fertosan" ........ & 12 & 0.9 & 29 & 32 & 22 & 9 & 36 & 1.1 & 27 & 26 & 26 & 12 \\
\hline$" Q R " \quad \ldots \ldots \ldots$ & 4 & 0.7 & 29 & 32 & 22 & 8 & 37 & 1.0 & 27 & 26 & 25 & 12 \\
\hline 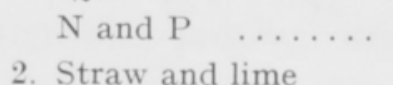 & 23 & 1.9 & 29 & 20 & 27 & 14 & 52 & 2.7 & 27 & 14 & 30 & 22 \\
\hline $0 \ldots \ldots \ldots \ldots$ & 6 & 0.5 & 23 & 30 & 17 & 19 & 22 & 0.5 & 17 & 31 & 18 & 24 \\
\hline$"$ Fertosan" ..... & 3 & 0.5 & 23 & 29 & 16 & 22 & 16 & 0.5 & 23 & 27 & 17 & 25 \\
\hline$" Q R " \quad \ldots \ldots \ldots$ & 2 & 0.5 & 26 & 30 & 18 & 17 & 14 & 0.5 & 25 & 27 & 19 & 22 \\
\hline $\begin{array}{l}\mathrm{N} \text { and } \mathrm{P} \quad \ldots \ldots \ldots \\
\text { 3. Straw }\end{array}$ & 31 & 1.4 & 27 & 25 & 19 & 27 & 52 & 1.9 & 21 & 14 & 23 & 34 \\
\hline $0 \ldots \ldots$ & 13 & 0.6 & 29 & 34 & 20 & 8 & 28 & 0.6 & 27 & 31 & 22 & 9 \\
\hline $\mathrm{N}$ and $\mathrm{P} \quad \ldots \ldots \ldots$ & 26 & 1.9 & 30 & 26 & 24 & 10 & 58 & 2.6 & 27 & 16 & 31 & 16 \\
\hline $\mathrm{N}, \mathrm{P}$ and $"$ Fertosan & 28 & 1.7 & 32 & 24 & 24 & 11 & 54 & 2.5 & 24 & 19 & 30 & 15 \\
\hline $\mathrm{N}, \mathrm{P}$ and $" \mathrm{QR} " \ldots$ & 29 & 2.0 & 29 & 26 & 26 & 11 & 55 & 2.4 & 25 & 18 & 29 & 15 \\
\hline
\end{tabular}

as a percentage of the original material, since these data show the absolute decomposition of the fraction containing mostly cellulose:

Treatment

1. Straw and manure

\begin{tabular}{|c|c|}
\hline $0 \ldots \ldots \ldots \ldots \ldots \ldots \ldots \ldots$ & 26 \\
\hline Fertosan..$\ldots \ldots \ldots \ldots \ldots$ & 28 \\
\hline${ }^{Q} Q R, \quad \ldots \ldots \ldots \ldots \ldots \ldots \ldots$ & 31 \\
\hline $\mathrm{N}$ and $\mathrm{P} \quad \ldots \ldots \ldots \ldots \ldots$ & 15 \\
\hline
\end{tabular}

2. Straw and lime

$0 \ldots \ldots \ldots \ldots \ldots \ldots \ldots \ldots . . . \ldots \ldots$

"Fertosan» ..............

${ } Q \mathrm{QR}, \quad \ldots \ldots \ldots \ldots \ldots \ldots \ldots \ldots$

$\mathrm{N}$ and $\mathrm{P} \quad \ldots \ldots \ldots \ldots \ldots \ldots$

3. Straw

$0 \ldots \ldots \ldots \ldots \ldots \ldots \ldots \ldots \ldots$

$\mathrm{N}$ and $\mathrm{P} \quad \ldots \ldots \ldots \ldots \ldots \ldots . . \ldots$

$\mathrm{N}, \mathrm{P}$ and Fertosan» $\ldots \ldots \ldots . . \ldots$

$\mathrm{N}, \mathrm{P}$ and $" \mathrm{QR}$ "
Sulfuric acid soluble organic matter as a percentage of the original dry matter after 6 weeks after 4 months

$\begin{array}{rr}28 & 24 \\ 28 & 23 \\ 29 & 23 \\ 17 & 7\end{array}$

$30-22$

17

$18 \quad 8$

Consequently, according to the results of these laboratory experiments, there occurred no evidence of any beneficial effect of the treatments with the preparations "Fertosan" and "QR". Although the conditions for humification were favourable in these experiments, neither the bacteria in "Fertosan» nor the activators in "QR» could 
Table 2. Composition of the humifying matter in the composts (Expressed as a percentage of dry matter.)

\begin{tabular}{llcl}
\hline & After 2 months & After 4 months \\
\cline { 2 - 3 } Treatment & Tot. N Ash & Tot. N Ash & $\frac{\text { Organic matter }}{\frac{\text { soluble in insoluble }}{\mathrm{HCl} \mathrm{H}_{2} \mathrm{SO}_{4}}}$ \\
\hline
\end{tabular}

1. Straw and manure

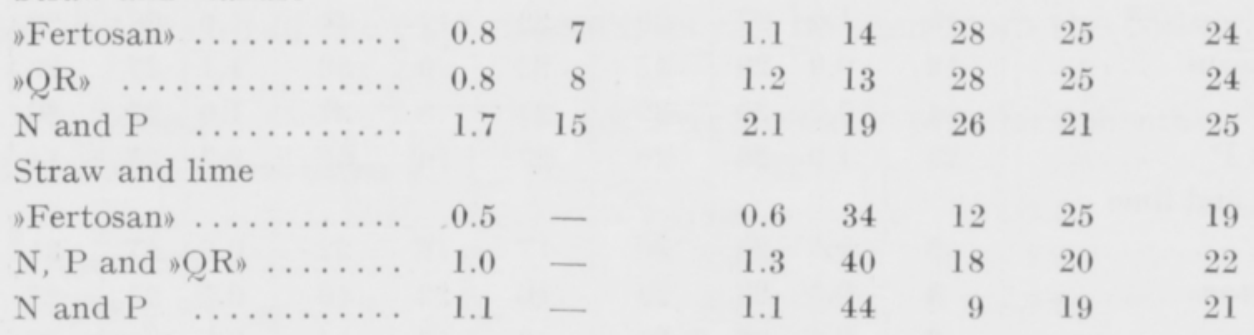

increase the activity of the normal microflora of decomposing straw. The amount and quality of this microflora seem to be controlled largely by the adequacy of the nitrogen and possibly of the phosphorus sources.

In the composts prepared on a larger scale in the field, temperature and moisture were minimum factors. It was of interest to find out, if the preparations would have any effect under these less favourable conditions.

The composts were not covered with soil, therefore the surface layers had a tendency to dry up, in spite of the watering. Since the composts were of small size, the undecomposed surface layers formed a large part of the mass. The samples for analyses were always taken from the middle of the heaps where the moisture was sufficient and where the most effective decomposition took place. For the whole experimental period the temperature in the composts remained almost equal to that of the air, and no significant differences between the various heaps occurred.

Table 2 shows the results from the analyses of the samples taken after the incubation period of two and four months. Here also only the data for the same series are comparable.

These results are not as marked as those of the laboratory experiments. Yet, even they show a tendency similar to that of the latter. The ash contents indicate a more effective decomposition in the composts with nitrogen and phosphorus as compared to those without mineral nutrients. Even the percentages of the sulfuric acid soluble organic matter are distinctly lower in the composts that received nitrogen and phosphorus, thus corroborating the former results. The differences in the colour and softness of the material from the various composts agreed with the view given by the chemical analyses.

\section{Summary and conclusions.}

The effect of the bacterial preparation "Fertosan» and of the possibly biodynamic preparation "QR" upon humification of rye straw was investigated in experimental 
series both under laboratory conditions and on a larger scale in the field. In all these experiments no evidence indicated that either of these preparations had accelerated the decomposition of rye straw. This could be established under the less favourable conditions in the field composts without mineral fertilizers as well as under the almost ideal conditions in pot experiments where applications of nitrogen and phosphorus were sufficient to satisfy the needs of a large microbial population. Consequently, according to the results of these experiments there seems to be no reason for using such preparations as "Fertosan» and "QR» in humifying rye straw. The decomposition of organic matter seems to depend more on the nitrogen and perhaps even on the phosphorus supply than on an inoculation of some bacteria or on an application of microbial "activators».

\title{
REFERENCES.
}

(1) Cholodny, N. 1930. Über eine neue Methode zur Untersuchung der Bodenmikroflora. Arch. Mikrob., 1, p. $620-632$.

(2) Kaila, A. 1949. Biological absorption of phosphorus. Soil Sci., 68, p. 279-289.

(3) Millar, H. C., Smith, F. B., and Brown, P. E. 1936. The base-exchange capacity of decomposing organic matter. Jour. Amer. Soc. Agron., 28, p. 753-756.

(4) Waksman, S. A. 1924. Influence of microorganisms upon the carbon-nitrogen ratio in the soil. Jour. Agr. Sci., 14, p. 555-562.

(5) - $\rightarrow$ 1931. Decomposition of the various chemical constituents etc. of complex plant materials by pure cultures of fungi and bacteria. Arch. Mikrob. 2, p. 136-154.

(6) - - - and Stevens, K. R. 1930. A system of proximate chemical analysis of plant materials. Ind. Engin. Chem., Anal., Ed. 2, p. 167-173.

\section{SELOSTUS.}

\author{
HAVAINTOJA "FERTOSAN"- JA "QR»-VALMISTEIDEN VAIKUTUKSESTA OLKIEN \\ HUMIFIOITUMISEEN.
}

Armi Kaila ja Anja-Meri PohjanpäÄ

Helsingin Yliopiston maanviljelyskemian laitos.

Parin viime vuoden aikana on maassamme mainostettu kahta erikoisvalmistetta orgaanisen aineksen humifioijana. Näistä »Fertosan»-niminen on myyjän ilmoituksen mukaan bakteeripreparaatti, jonka sisältämä bakteerikanta pystyy ilmiömäisen tehokkaaseen orgaanisen aineksen hajoittamiseen. Toinen, "QR"-valmiste, on todennäköisesti jonkinlainen »biodynaaminen» preparaatti, koska siinä ei ilmoiteta olevan bakteereja, vaan tiettyjä aineita, jotka kiihdyttävät hajoitusta suorittavien mikrobien toimintaa. Molempien väitetään pystyvän hajoittamaan olkia, jopa ilman typen lisäämistä, niin tehokkaasti, että jo kuudessa viikossa saadaan oljista hyvänlaatuista humusta. 
Näiden valmisteiden tehon tutkimiseksi suoritettiin sarja kokeita sekä laboratoriossa että suuremmassa mittakaavassa. Niissä verrattiin „Fertosan»- ja „QR»-käsittelyn vaikutusta typpi- ja fosforilisäyksen vaikutukseen sekä karjanlantaa että kalkkia käyttäen valmistetuissa olkikomposteissa. Lisäksi tutkittiin, pystyvätkö valmisteet tehostamaan hajoitusta komposteissa, joissa on typpeä ja fosforia riittävästi tyydyttämään runsaan mikrobikasvuston tarpeet.

Missään tapauksessa ei voitu havaita, että kumpikaan valmisteista olisi edistänyt olkien hajaantumista. Sen sijaan typen ja fosforin erittäin edullinen vaikutus ilmeni selvästi kaikkien koesarjojen tuloksista.

Edellä selostetun tutkimuksen perusteella ei siis näytä olevan syytä käyttää »Fertosan»- tai »QR»valmisteita rukiin oljen humifioimiseen.

\section{MAATALOUSTIETEELLINEN AIKAKAUSKIRJA} TOIMITUSKUNTA

\author{
Ilmari Poijärvi \\ Päätoimittaja
}

\author{
E. A. Jamalainen \\ Toimitussihteeri
}

Tikkurila. Puh. 831244 ja 831308

Tikkurila. Puh. 831419 ja 831318

E. Kitunen, J. O. Sauli, Erkki Kivinen, Aarne Virtamo

MAATALOUSTIETEELLISTÄ AIKAKAUSKIRJAA

ilmestyy 4 vihkoa vuodessa sisältäen kukin 2-4 painoarkkia

Käsikirjoitukset lähetetään joko päätoimittajalle tai toimitussihteerille (os. Tikku= rila) tai jollekin toimitusvaliokunnan jäsenelle

\section{SUOMEN MAATALOUSTIETEELLINEN SEURA}

\section{Puheenjohtaja :}

Professori Nils Westermarck,

Iso Puistotie 1, Munkkiniemi

Varapuheenjohtaja :

Professori Onni Pohjakallio,

Viikin kartano, Helsinki

\section{Sihteeri:}

Professori V. Vainikainen,

Kasarmik. 38 A 8, Helsinki

Rahastonhoitaja :

Maisteri Aarne Virtamo,

Maataloushallitus, Helsinki

Kirjastonhoitaja :

Maisteri Majlis Tulander, Hallituskatu 3, Helsinki 